\title{
BRUK AV FOKUSGRUPPEINTERVJU
}

Fokusgruppeintervju brukes i økende grad i kliniske forskningsstudier innen helsefag.

Tekst: Anners Lerdal og Bengt Karlsson. Begge forfatterne førsteamanuensis ved Høgskolen i Buskerud.

Hensikten er å samle kvalitative data fra en mindre gruppe personer om et angitt tema. Gjennom grupsubjektive opplevelser erfaringer synspunkter eller holdninger i forhold til et fenomen eller en spesifikk situasjon (11. Temaet blir gitt av forskeren og kan være knyttet til en spesiell situasjon, et problem, en erfaring, et helsetjenestetilbud eller et annet avgrense fenomen. Metoden egner seg godt til å innhente data artikkelen er å gi en kort innføring i hva som kjenn tegner et fokusgruppeintervju og noen praktiske rå knyttet til gjennomføringen. Til inspirasjon vil vi ogs gi noen eksempler på huordan denne metoden har vart

\section{$>$ INNLEDNING}

Tradisjonelt or metoden kjent fra studier av psykologiske og sosiale effekter av propaganda innen mediaforskning, blant annet under andre verdenskrig
Fokusgruppeintervju ble også anvendt ved utvikling av Fokusgruppeintervju ble også anvendt ved utvikling av (1). Potensielle kjøpere ble samlet i fokusgrupper for . menes tanker 0 folelser for produktet fikk de kunnskaper som kunne brukesividereutvikling avvaren strategier for markedsføring.

Med det sterke fokuset vi har i dag på brukermed virkning, kan fokusgruppeintervju egne seg til å fa innsikt i hvordan ulike pasientgrupper erfarer dagliglivet med helseproblemer, samt deres behov og onsker om helsetjenester. På denne måten kan brukere gis innflytelse og fa en mer aktiv rolle I utforming a helsien (2). Hummvar med idealer fra empowermenttokusgruppeintervjuet er en metode som harmoner med designet for et handtingsorientert forskningssamarbeid laksjonsforskningl og kan bidra til læring ved refleksjoner over egen klimisk praksis. Noe somigjen kan bidra tit ny innsikt i fremtidig handling.
Tillgren og Wallin (1) fremholder at fokusgrupper kke handler om a beskrive generelle betraktninger Man forsøker derfor gjerne å begrense generelle vurderinger og utsagn. Og heller stimulere til fyldigere beskrivelser av deltakernes oppfatninger, ønskemå eller oplevelse av problemer i relasjon til det fenomenet eller den situasjonen som tematiseres. Madriz (4) fremnolder at fokusgrupper er velegnet nar man ønsker à utvikle kunnskap somgir en dypere forståelse nnelse i en grupp

\section{$>$ FOKUSGRUPPEINTERVJU OG} GRUPPEINTERVJU Fokusgruppeintervjuet brukt i forskningssammenheng gruppeintervjuet legges det til rette for dataskaping gjennom at deltakerne samtaler med hverandre, mens dialogen $i$ et gruppeintervju i større grad skjer mellom forskeren og de ulike deltakerne (5). Morgan (6) og Krueger (7) påpeker at til forskjell fra individuelle intervjuer fremskaffer fokusgrupper informasjon fra en gruppedynamisk interaksjonsprosess. Denne kan brukes bevisstiforhola til det à skape data eller innsikt som vanskelig ville latt seg produsere uten dynamikgruppeden. Ved en storre frihet samtaten mellom gruppedeltakerne gis deltakerne mulighet til en friere attryksform, for eksempel ved a fortelle gode og/ fokus. Slikkan forskeren fa tilatert temaet som er være vanskeligere å fo frem ved gruppeintervju, hvor forskeren stiller spørsmål til de ulike medlemmene gruppen som så avgir svar til forskeren (2). Madriz (4) argumenterer for bruken av fokusgruppeinterviuer studier der man særlig er opptatt av holdninger, erfaringer og hvordan kunnskap produseres og brukes en bestemt kulturell kontekst. Dette giør fokusgruppeintervjuet spesielt egnet til ă beskrive dominerende verdier I spesielle kulturer og subkulturer. Som for eksempel en arbeidskultur eller personalets holdnin ger til minoriteter (2). Brataas (8) doktorgradsarbeid, hvor hun viser hvordan bruk av fokusgruppeintervju ga informasjon om tankeprosesser hos sykepleiere i en gitt fagkultur, er et eksempel pa dette. Studien viste at det gruppemedlemmene forsto som god sykepleiefag-
lig kommunikasjon, var basert i felles verdier og fag- kultur. Fokusgruppeintervjuer kan brukes til å samle data til en selvstendig studie, og de kan gjennomføres første trinn forstudie til en intervensjonsstudie. Som

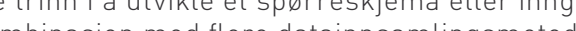
$(5 ; 9)$.

\section{$>$ PLANLEGGING AV FOKUSGRUPPE-} INTERVJUER

pessursbesparende metode piser kusjoner med et mindre utvalg fra en populasjon. trygt gruppemiljø og åpenhet i gruppen er vesentlig for å skape en fri diskusjon mellom medlemmene. Dataskapingen skjer konsentrert ved at flere personer sammenlikner erfaringer og tolkninger under intervjuet. Pa den andre siden kan det være praktisk vanskelig å finne tidspunkt hvor alle gruppemedlemmer kan møtes. Som et ledd i a skape en trygg og god atmosfære for intervjuene, kan man velge et trivelig rom med gode stoler og eventuelt noe a drikke peintervice spat foreg̊ ag an de skat arrangeres a dagtid eller kveldstid. Antall grupper og hvor mana møter man skat ha med de ulike gruppene bar bestemmes ut fra studiens problemstilling og po̊ bakgrun tilgiengelige ressurser. Antall grupper istore studier kan variere fra seks til 50 (2). Man kan også velge følge gruppene over lengre tid giennom såkalte fle stegsfokusgruppeintervju. Alle disse spørsmålene eksempler på forhold som er viktige å avklare i tidlig fase av prosjektet $(10$

\section{$>$ REKRUTTERING AV DELTAKERE}

Studiens problemstilling gir naturligvis føringer for hvem man ønsker å rekruttere. Selv om det er mulig hetsutvelging) er det vanligst å benytte en form for hensiktsmessig utvelgelse (11). Noen anbefaler homogene grupper med personer som har mest mulig lik bakgrunn og erfaringer. Men det kan i noen tilfeller ogsa argumenteres for at gruppen settes sammen me heterogent (2). I en del tilfeller kan hierarkisk rangordning mellom gruppemedlemmene hemme diskusjone i gruppen ved a skape en for sterk usymmetri. Antall deltakere i gruppen bør være hensiktsmessig. Mens nyere titeratur ofle anbefater at en fokusgruppe bestar

\section{ROLLEN SOM MODERATOR}

( oppgave er å lede og holde fokus i interviuet og oppmuntre til diskusjon mellom deltakerne. Assisterend moderator skal observere gruppedynamikken. oppsummere innholdet med jevne mellomrom og hielpe ti ă sentrere diskusjonen omkring de vesentlige temaen samtalen 112. Fokusgruppemotet varer van ligvis en til to timer. Moderatorens introduksjon til den første gruppesamtalen er svært viktig (13). Etter à ha ønske a a klargjøre hensikten med fokusgruppeintervjuet. For man presenterer åpningsspørsmąlet til gruppen dan grus det a presentere «kjørereglene» for hvordan gruppediskusjonen bør forega (13). Det er viktig a opptordre deltakerne til à snakke med og th hverfokus rempertit moderatoren. Gjennomfor ing av et flyre og forholde seg til bo̊d innholdeti diskusjonene J selve grupedynamikken. Fokuset for samtaten er . Gurdan moderator forklarer hensikten med fokusgruppen og introduserer temaet, vil styre innholdet hva deltakerne samtaler om. Å fremme en gruppedynamikk hvor de ulike medlemmene får slippe til er viktig og fordrer at moderator har innsikt i håndterin av gruppeprosesser. Gruppedynamikken bør bidra til at deltakerne får mulighet til å utdype og klargiøre sit syn pả saken som diskuteres (1). Eventuelle uenigheter mellom gruppemedtemmene kan føre til at de gir fylbigere beskivelser av sine standpunkter og klargier begrunnelsene for disse.

\section{$>$ TO STRATEGIER}

er å tro at man uten vider

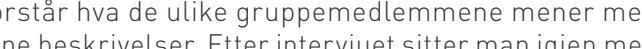
mange utsager. Etter intervjuet sitter man igjen moderator. Men man mangler en fyldig beskrivels av hva gruppedeltakerne egentlig la I utsagnet. For unnga dette er det viktig at moderator gjentar sentrate begreper eller utsagn som blir brukt. Og opptordrer dellakerne til a utdype hva han/hun egentlig legger det. Mens samhandingen mellom deltakerne under intervjuet pa den ene siden kan begrenses ved at moderator styrer for mye, kan det ogsä begrenses ved at en er for noen ra er svart dominerende og at moderator rartor ruderes. Deke kan ivjen vare en svakhet og gjore den spontane samhandlingen og diskujonen mellom dettakerne mindre (5). Po bakgrunn av problemstillingen man ønsker 
en av disse to moderatorstrategiene. Hvis hensikten er å forstå deltakernes tenkning på deres premisser, kan man velge en løs struktur. Her er det deltakernes interesser som dominerer og samtalen karakteiseres av dialog mellom disse (14). Hvis hensikten derimot er å få svar på mer spesifikke spørsmål, vi forskerens interesse I større grad dominere gjennom spørsmål og styring av innholdsdiskusjonen. Dialoge vi da i større grad skje mellom moderatoren og de enkelte deltakerne (14). Det er vanlig a gjøre opptak av samtatene. Opptaket skrives uti tekst Iverbatim somineste omgang er gjenstand for analyse. Itillegg for eksempel observasjoner, eller fra utater deltakerne snakker med lav stemme og det er fare for dårlig opptak.

\section{> FLERSTEGSFOKUSGRUPPEINTERVJU}

relativ nytt tibud med opprettelse av ambutante akuttean ved Distriktspsykiatriske sentre. Teamene ska greres suplement ispesiatishelsetjenesten og integreses i detakutte ljenestetibudet. Teamet folger opp bindelse med like psykisk kriser i personen milja. Follo akuttem pyki skikt team. Dette teamether arbeidet med systematisk kunnskapsutvikling av sin kliniske praksis over flere år (15). Den lokate oppfalgingen av personer som er i psykisk krise er i liten grad systematisk beskrevet og evaluert. På bakgrunn av teammedlemmenes $ø$ nske om å beskrive egne klinisk erfaringer og metoder «nedenfra», bestemte man seg for å bruke flerstegsfokusgruppeintervjuer (FGI) som metode. Dette er en metode hvor man giennomfører en serie fokusgrupper over tid. I denne studien valgte man a ta utgangspunkt i beskrivelser av samhandlingssituasjoner med de kriserammede og opptølgingstibude tra teamet. Disse metodebeskrivelsene ble systematisk skriftliggjort for senere å kunne evalueres. Vi vi nå beskrive hvordan flerstegsfokusgruppeintervjue ble brukt som metode for dataskaping og hvordan da ble analysert.

Gjennomføringen av de enkelte fokusgruppeintervjuene foregikk i tre trinn; planlegging, intervju o analyse. I planleggingsfasen ble det gjort en foreløpig fokus under interviuet. Fokusgruppeinterviuet bu lede av en moderator som var forsker og som styrte bo innhold og prosess under intervjuene. Samme person ledet hele prosessen. Under selve intervjuet fors $ø$ kte moderator å få data om den personlige erfaringsbaserte fagkunnskapen. Det ble stilt spørsmål om deltakernes subjektive opplevelser omkring det angit temaet. Et eksempel på et tema var; «Hva er en psykisk krise?». Man ønsket å få frem flest mulige og detaljer beskrivelser, særlig i de første intervjuene. Mot slutten av intervjuene var hensikten med spørsmålene a få nøkkelinformasjor henskten mamt à tydetiggiøre likheter og forskjeller blant teammedlemmene. Fra og med det andre intervjuet startet hvert intervju med en gjennomlesning av en foreløpig, syntetisert og skriftlig analyse av det forutgående intervjuet. Hvert intervju gjennomgikk en fase hvor målsettıngen var å lage en rremstilling av arbeidsmetodente) i follo akutteam pa et gitt tidspunkt. En klinisk arbeidsmetode som kunne gjøres til gjenstand for en systematisk evaluering. Sparsm he foldelig merog mer spisset ogrettet morusk ble folgelig mer og

Syv fokusgruppeintervjuer á tre timer utgjorde datagrunnlaget for analysen. Hvert interviu ble giort til gienstand for en hermeneutisk innholdsanalyse i fire trinn. De fire trinnene $i$ analysemetoden fokuserte på: 1l å få et helhetsinntrykk, 2l å identifisere i de enkelte meningsdannende enheter og 4 l å samforfatte betydningen av dette. Ther analyse gjorde forskeren en tematisering av meningsdannende enheter. Disse temaene ble ytterligere utdypet og presisert Ded at de ble brakt inn I neste fokusgruppeintervju. Dette ble gjort ved først a la teammedtemmene lese den syntetisert analysen fra forrige intervju for der列

\section{$>$ TILPASNING AV HELSETJENESTETILBUD} å teste ut et lærings- og mestringsopplegg for tenåringer med diabetes type I. I Tyskland var det allerede utviklet et slikt undervisningsprogram for voksne som bestod av syv unersundervising over en uke. Opplega fá kunnskap om huordan gode resultater (18). For undervisningsopplegget ville passe inn i hverdagen til tenåringeri Nord Irland, giennomfarte Chaney fem fokusgruppeintervjuer med 21 tenåringer med diabetes type I. Tenåringer ble rekruttert fra tre akuttsykehus i Nord Irland. Datamaterialet ble analysert ved hielp aven tematiskinnholdsanalyse. Det var stor interesse blant deltakerne for et undervisningsopplegg. Mange av ungdommene fortalte om frustrasjon og skyldfølelse over vanskeligheter og komplekse problemstilinger som diabetessykdommen skapte i hverdagen deres. Flere følte seg isolert og alene med sine problemer Ungdommene ga Imidertid klart uttykk for at de ikke kunne tenke seg a delta pa et undervisningsopplegg som gikk over en hel uke. I stedet var de villige til a della pa en tretimers saming en kveld i uken over grupper kan brukes til å skreddersy et lærings- og mestringstilbud for målgruppen som gjør det realistisk for deltakerne a delta pa undervisningsopplegge og møte opp flest mulig ganger. Det nye tilpassed laringstibudet testes na ut ienrandomisert kontrollert studio ved fire akutsykehus i Nord-lland und

Eksemplene vi har beskrevet illustrerer hvordan fokusgruppeintervjuer kan brukes til å beskrive o

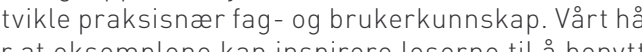
ulike former av fokusgruppeintervjuer i arbeidet med systematisk kunnskapsutvikling i klinisk praksis. Refe ranselisten gir også muligheter for videre og mer utdypende lesning om fokusgruppeinterviu.

\section{REFERANSER}

Wilitlgren $P$, Waltin E. Fokusgrupper - historikk, struktur oc

Kitzinger J. Qualitative research. Itroducing focus groups.

3) Hummelvoll JK, Sunde AS, Severinsson E. Om å møte mennesker med manisk lidelse - en interven
kiatrien. Hogskolen i Hedemark: $3 / 200$ (4) Madriz E. Focus Groups in Feminist Research. I: Denzin NK, on: Sage, Publications, Inc. 2000. s.835-50.

5) Morgan DL. Focus groups as qualitative research. 2. utg.

(6) Morgan DL. Focus Groups as Qualitative Research. London

B) Brataas HV. Helse i hvert møte? Kreftpasienters oppfatninger gelse Doktorgradsaybandling, Fakultet for samfunnsviten skap og teknologiledelse: NTNU, Trondheim. 200 (9) Halkier B. Fokusgrupper. Frederiksberg: Samfundslitteratur

(10) Morgan DL. Planning Focus Groups. Thousand Oaks: Sage

(11) Wibeck V. Fokusgrupper - om fokuserade gruppintervjuer Re Krueger RA. Focus Groups. A Practical Guide for Applied Research. London: Sage Publications, Inc. 1994. (13) Krueger RA. Moderating Focus Groups. Thousand Oaks: (14) Morgan DL. Focus Group Interviewing. I: Gubrium JF. Method. Thousand Oaks: Sage Publications, Inc.; 2002. s.141-59. (15) Karlsson B. Nye historier - om kunnskapsutviklingen i Follo
akutteam. Tidsskrift for psykisk helsearbeid 2006;3:142-53. (16) Malterud K. Kvalitative metoder I medisinsk forskning - en inforing. 2. utg. Osto: Universitetstortaget. 2003 (17) Kvale S. Interview - en introduktion til det kvalitative fors (18) Jorgens V, Grusser M, Bott U, Muhlhauser I, Berger M. to general internal medicine departments. Diabetologia 